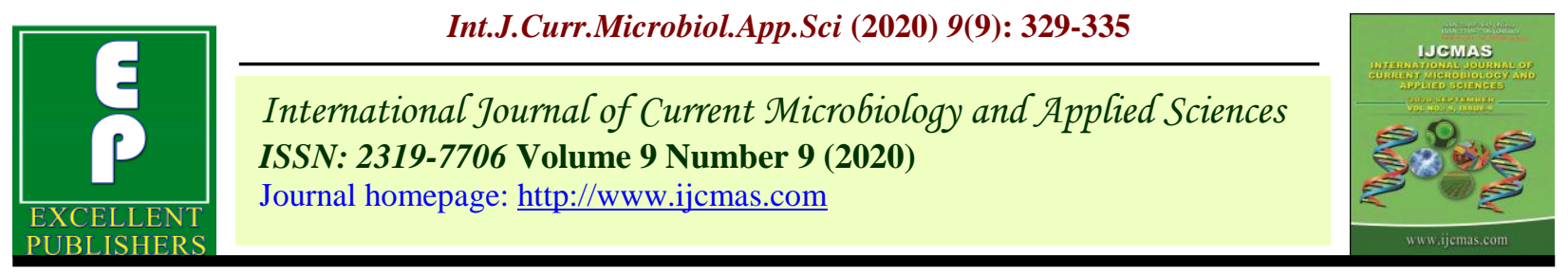

Original Research Article

https://doi.org/10.20546/ijcmas.2020.909.042

\title{
Studies on Genetic Variability and Heritability in Turmeric (Curuma longa L.)
}

\author{
K. Mamatha", M. B. N. Rao, BVK. Bhagavan, K. Umajyothi, \\ M. Anuradha and K. Sivaraju
}

Horticultural Research station, Kovvur, DR YSR Horticultural University, Venkataramannagudem, Andhra Pradesh, India -534350

*Corresponding author

\section{A B S T R A C T}

\begin{tabular}{|l|}
\hline K e y w o r d s \\
$\begin{array}{l}\text { Turmeric, } \text { Curcuma } \\
\text { longa, Genetic } \\
\text { variability }\end{array}$ \\
\hline Article Info \\
\hline $\begin{array}{l}\text { Accepted: } \\
\text { 04 August } 2020 \\
\text { Available Online: } \\
\text { 10 September } 2020\end{array}$ \\
\hline \hline
\end{tabular}

\begin{abstract}
Genetic variability, phenotypic and genotypic coefficient of variation, heritability and genetic advance was studied for eighty three turmeric genotypes collected from different sources of India including local collections. High phenotypic coefficient of variation, and genotypic coefficient of variation was obtained for number of secondary rhizomes, whereas, highest heritability was observed for curcumin content and curing percentage, indicating that these characters are important in crop improvement which are contributed by additive genes where the improvement can be made by simple selection. The selection for these characters will be more effective in, Vontimitta for number of secondary rhizomes, CLL 335 for number of primary rhizomes and yield per plant and curcumin content for $\mathrm{T}$ Sundar. Thus results indicated that in turmeric individual plant selection based on desirable characters could be effectively utilized for extraction of superior genotypes.
\end{abstract}

\section{Introduction}

Knowledge of germplasm diversity has a significant impact on genetic improvement of crop plants. The variation in the genetic make-up, interaction with environment, dictates the observable pattern of diversity being shown by most of the living organisms. Development of varieties with high yield levels coupled with desired quality attributes requires information on the nature and extent of variability available in the germplasm collections. For any breeding programme, genetic diversity is the raw material to a breeder, since genetic variation determines the potential for making gains from selections and resolving their phylogenetic relationships. In this regard, studies providing the information regarding the crops genetic diversity are essential especially in the crops like turmeric which is having a high export potential. India is having a high degree of variability of turmeric. Though India enjoys the monopoly in turmeric production and export, because of its ever increasing demand in both food and pharmaceutical industries, there is pressing need to further increase the productivity of turmeric. However to increase the productivity, information regarding the crop genetic diversity is essential. 
Considerable genetic variation in turmeric for various traits of economic importance has been reported by various workers (Babu et al., 1993, Lynrah et al., 1998, Hazra et al., 2000, Sinker et al., 2005, Singh et al., 2012, Jan et al., 2012, Rajyalakshmi et al., 2013, Singh and Ramakrishna, 2014, Prajapati et al., 2014 and Verma et al., 2015).

\section{Materials and Methods}

An experiment was conducted at Horticultural Research station Kovvur, to find out the genetic divergence in 83 turmeric accessions. The experimental area has got a tropical monsoon climate with south-west monsoon from June to September, north-east monsoon in October - November and dry spell from December to May with summer showers in April and May. Average temperature varies from $23^{\circ} \mathrm{C}$ to $39^{\circ} \mathrm{C}$ and the annual rainfall is about $110 \mathrm{~cm}$. The experiment was laid out in augmented block design consisting of 11 augmented blocks in which three checks and ten entries were planted. Each accession was raised in a single row plot of $4.5 \mathrm{~m}$ length at spacing of $22.5 \mathrm{~cm}$ between plants accommodating 20 plants in each row and five plants were selected and tagged from each accession for collection of data. The standard packages of practices were followed throughout the study. Five tagged plants from each accession were used for recording the observations and the mean values were subjected for statistical analysis. Analysis of variance for each character was carried out by using the Augmented Design method as per the procedure outlined by Federer (1956). The significance test was carried out by referring to ' $F$ ' table value given by Fisher and Yates (1963). Genotypic and phenotypic coefficients of variation were computed according to Burton (1952). Heritability in broad sense refers to the proportion of genetic variance to the total observed variance in the population. It has been estimated as per the formula given by Lush (1940). Genetic advance as per cent mean was worked out for each character adopting the formula given by Johnson et al., (1955)

\section{Results and Discussion}

The genetic parameters, viz., phenotypic coefficient of variation (PCV), genotypic coefficient of variation (GCV), heritability in broad sense and genetic advance as per cent mean were estimated for all the characters under study (Table 1). The germplasm lines exhibited a wide range of variability for all the characters.

Analysis of variance revealed highly significant variability for all the characters under study. In general the PCV estimates were higher than the GCV estimates indicating the influence of environment on the expression of these characters and possibility of obtaining very high selection response in respect of these characters.

The highest percentage of phenotypic and genotypic coefficient of variation was observed for number of secondary rhizomes (51.41 and 47.55 respectively) followed by length of leaf petiole (34.69 and 30.85 respectively) and yield per plant (33.03 and 29.83 respectively). The lowest percentage of PCV and GCV was observed for days to maturity (5.14 and 2.88 respectively).

The magnitude of difference between PCV and GCV was less for curcumin content (0.01) followed by leaf width (0.15) and curing percent (0.15). While the highest difference was observed for number of primary rhizomes (18.02) followed by girth of primary rhizomes (12.76). The highest PCV and GCV was observed for leaf area $(24.38 \&$ 23.55), number of tillers per plant $(31.71 \&$ 30.59), number of mother rhizomes (26.9\&20.29), and curcumin content 
(30.2\&30.19) indicating the large influence of environment on the expression of these characters. Whereas highest PCV and moderate GCV was noticed for girth of mother rhizomes (22.42\&19.09), number of primary rhizomes $(29.71 \& 11.71)$, length and girth of secondary rhizomes $(25.89 \& 18.57)$, yield (25.92\&17.3), curing percentage (20.03\&19.88) emphasizing these characters to be potent variable. Hence selection will be more effective with respect to these characters.

The moderate PCV and GCV estimates were observed for plant height (16.21\&15.83), basal stem diameter (14.03\&13.43), leaf length (17.00\&16.34), leaf width (12.24\&12.09), length of mother rhizomes (19.24\&10.33), and length of primary rhizomes (15.95\&13.26). Whereas moderate PCV and low GCV was recorded for number of leaves (10.18\&9.5), The PCV and GCV estimates were very low for days to maturity. (5.141 and 2.878 respectively).

The PCV estimates were high for number of secondary rhizomes than GCV indicating that the influence of environment on the expression of this character is very meager and it may differ with the genetic makeup of the accession.

The findings are in corroboration with earlier workers (Pathania et al., (1988), Indiresh et al.(1992), Babu et al., (1993), Lynarah et al.(1998), Singh et al., (2003), Sinker et al., (2005) Rao et al., (2004), Jan et al., (2011), Jan et al., (2012), Rajyalakshmi et al., (2013), Singh et al., (2013), Singh and Ramakrishna (2014), Prajapati et al., (2014) and Verma et al., (2015) and Jayasree et al., (2014).

The heritability estimates help the breeders in selection based on the phenotypic performance. Although PCV and GCV reveal the extent of genetic variability present, they do not indicate the extent of heritable variation. So that the selection can be effective and respectable. The practical implications in breeding programmes are based on magnitude of heritable variation of the character concerned.

Out of 21 characters studied, all the characters have exhibited high heritability except number of mother rhizomes, length of mother rhizomes, number of primary rhizomes, girth of primary rhizomes, length and girth of secondary rhizomes and days to maturity.

High heritability was observed for curcumin content $(99.9 \%)$, curing percentage $(98.5 \%)$, yield $(81.6 \%)$, plant height $(95.4 \%)$, basal stem diameter $(91.2 \%)$, number of leaves $(87.2 \%)$, leaf length $(92.4 \%)$, leaf width $(97.6 \%)$ leaf area $(93.3 \%)$,length of leaf petiole $(79.1 \%)$,girth of mother rhizomes (72.5\%) length of primary rhizomes $(69.1 \%)$ and number of secondary rhizomes $(85.5 \%)$ indicating that these characters are important in crop improvement as major part of the phenotypic variability in these characters was contributed by additive gene effects and hence improvement can be made by simple selection. Similar findings were reported by Pathania et al., (1988), Babu et al., (1993), Lynarah et al., (1998) Singh et al., (2003), Singh et al., (2012), Rajyalakshmi et al., (2013), Jayasree et al., (2014) and Verma et al., (2015).

Whereas moderate estimates of heritability was recorded for the traits, number of mother rhizomes (56.9\%),length of secondary rhizomes (51.4\%) and days to maturity $(31.3 \%)$ indicating the considerable influence of environment and low estimates of heritability were recorded for length of mother rhizomes $(28.8 \%)$, number of primary rhizomes $(15.5 \%)$ and girth of primary rhizomes $(12.2 \%)$. 
Table.1 Estimates of variability and genetic parameters for yield and yield attributes in turmeric

\begin{tabular}{|c|c|c|c|c|c|c|c|}
\hline S. No. & Character & Mean & Range & $\begin{array}{l}\text { Phenotypic } \\
\text { coefficient of } \\
\text { variation }\end{array}$ & $\begin{array}{l}\text { Genotypic } \\
\text { coefficient of } \\
\text { variation }\end{array}$ & $\begin{array}{c}\text { Heritability } \\
\text { (broadsence) } \\
(\%)\end{array}$ & $\begin{array}{c}\text { Genetic } \\
\text { Advance as per } \\
\text { cent Mean }(\%) \\
\text { (GAM) }\end{array}$ \\
\hline 1 & Plant height $(\mathrm{cm})$ & 146.56 & $92.26-190.53$ & 16.21 & 15.83 & 95.4 & 31.85 \\
\hline 2 & Basal stem diameter $(\mathrm{cm})$ & 10.68 & $6.84-16.89$ & 14.06 & 13.43 & 91.2 & 26.43 \\
\hline 3 & Number of leaves & 7.89 & $4.48-10.31$ & 10.18 & 9.50 & 87.2 & 18.28 \\
\hline 4 & Leaf length(cm) & 62.09 & $38.8-85.87$ & 17.00 & 16.34 & 92.4 & 32.36 \\
\hline 5 & Leaf width $(\mathrm{cm})$ & 15.17 & $10.34-19.49$ & 12.24 & 12.09 & 97.6 & 24.61 \\
\hline 5 & Leaf area $(\mathrm{cm} 2)$ & 683.73 & $204.52-1205.18$ & 24.38 & 23.55 & 93.3 & 46.84 \\
\hline 6 & Number of tillers & 1.95 & $0.89-4.39$ & 31.77 & 30.59 & 92.7 & 60.68 \\
\hline 7 & Length of leaf petiole $(\mathrm{cm})$ & 11.05 & $4.33-24.66$ & 34.69 & 30.85 & 79.1 & 56.50 \\
\hline 8 & Number of mother rhizomes & 2.40 & $1.02-4.59$ & 26.90 & 20.29 & 56.9 & 31.52 \\
\hline 9 & Length of mother rhizome (cm) & 6.64 & $2.10-11.17$ & 19.24 & 10.33 & 28.8 & 11.43 \\
\hline 10 & Girth of mother rhizome $(\mathrm{cm})$ & 10.75 & $5.20-15.40$ & 22.42 & 19.09 & 72.5 & 33.47 \\
\hline 11 & Number of primary rhizomes & 5.82 & $0.31-9.98$ & 29.73 & 11.71 & 15.5 & 9.49 \\
\hline 12 & Length of primary rhizome $(\mathrm{cm})$ & 7.97 & $4.69-12.27$ & 15.95 & 13.26 & 69.1 & 22.71 \\
\hline 13 & Girth of primary rhizome $(\mathrm{cm})$ & 7.25 & $3.26-11.32$ & 19.60 & 6.85 & 12.2 & 4.93 \\
\hline 14 & Number of secondary rhizomes & 6.39 & $0.64-15.81$ & 51.41 & 47.55 & 85.5 & 90.58 \\
\hline 15 & Length of secondary rhizome $(\mathrm{cm})$ & 4.75 & $0.80-10.44$ & 25.89 & 18.57 & 51.4 & 27.44 \\
\hline 16 & Girth of secondary rhizome $(\mathrm{cm})$ & 5.38 & $1.85-10.65$ & 25.92 & 17.30 & 44.6 & 23.79 \\
\hline 17 & Yield per plant (g) & 352.90 & $162.75-755.42$ & 33.03 & 29.83 & 81.6 & 55.50 \\
\hline 18 & Rhizome yield ( $\left.\mathrm{t} \mathrm{ha}^{-1}\right)$ & 27.87 & $12.18-59.72$ & 33.03 & 29.83 & 81.6 & 55.50 \\
\hline 19 & Curing $(\%)$ & 21.92 & $9.96-31.46$ & 20.03 & 19.88 & 98.5 & 40.64 \\
\hline 20 & Curcumin content $(\%)$ & 3.09 & $1.36-6.73$ & 30.20 & 30.19 & 99.9 & 62.16 \\
\hline 21 & Days to maturity & 215.90 & $186.17-248.75$ & 5.14 & 2.88 & 31.3 & 3.32 \\
\hline
\end{tabular}

PCV, GCV and Genetic Advance as per cent Mean: Low = 0-10\%; Medium = 10-20\%; High = $20 \%$ above

Heritability: Low $=$ Less than 30\%; Medium = 30-60\% $;$ High $=$ More than $60 \%$ 
Highest estimates of heritability observed for curcumin content (99.09) was in conformity with the study reported by Lynarh et al., (1998), Pathania et al., (1988) declaring the possibility of improvement of fresh turmeric yield through clonal selection for rhizome yield and its component characters and suggesting that clonal selection for curcumin content would be more effective. High heritability for plant height and leaf width as well as moderate to low heritability for yield have been reported by Babu et al., (1993). While, Prajapati et al., (2014) registered low heritability for plant height, leaf length, leaf width, number of leaves, number of tillers and curcumin content.

Heritability along with genetic advance is more helpful in predicting the gains under selection than heritability estimated alone (Johnson et al., 1955). In the present study, genetic advance as percentage mean ranged from 3.32 (Days to maturity) to 90.58 (number of secondary rhizomes).

High heritability along with high genetic advance was observed for plant height, stem diameter, leaf length, leaf width, leaf area, number of tillers, length of leaf petiole, number of mother rhizomes, girth of mother rhizomes, length of primary rhizomes, number of secondary rhizomes, length of secondary rhizomes, yield, curing percentage and curcumin content indicating the predominance of additive genes and pave the way for improvement of those characters in individual plant selection. Similar findings were reported by Pathania et al., (1988) and Lynrah et al.(1998). Heritability and genetic advance were observed to be high for rhizome yield and number of tillers per plant (Rajyalakshmi et al., (2013). According to Manohar et al., (2004), there was moderate to high heritability and genetic advance for cured yield, Fresh weight of mother rhizomes and number of secondary rhizomes.
High variability with appreciable genetic advance was reported for rhizome yield, days taken for maturity, number of leaves, number of fingers, yield of secondary rhizomes and plant height by Jan et al., (2012).

Highest percentage of genetic advance as percent mean was recorded for number of secondary rhizomes and this finding is in conformity with Philip \& Nair (1985), Sinker et al., (2005) and Singh et al., (2003).

Low heritability coupled with low genetic advance was noticed for days to maturity indicating the large influence of environment for the expression of this character. Similar findings were reported by Singh and Ramakrishna (2014).

In conclusion the extent of genetic variability breeders to effectively design the breeding programmes for characters under improvement. Besides genetic variability, the knowledge on heritability and genetic advance measures the relative degree to which a character is transmitted to its progeny, thereby helps the breeder to employ a suitable breeding strategy to achieve the objective quickly.

The selection for these characters will be more effective in, Vontimitta for number of secondary rhizomes, CLL 335 for number of primary rhizomes and yield per plant and curcumin content for $\mathrm{T}$ Sundar. Thus results indicated that in turmeric individual plant selection based on desirable characters could be effectively utilized for extraction of superior genotypes.

\section{Acknowledgments}

The Authors are thankful to Dr YSR Horticultural University, Venkataramannagudem for its support. 


\section{References}

Babu, K.N, Sasikumar, B, Ratnambal, J, George, $\mathrm{J}$ and Ravindran, P.N. 1993.Genetic variability in turmeric (Curcuma Longa L.). Indian Journal of Genetics.53(1): 91-93.

Burton,G.W.1952.Quantitative inheritance in grasses. Proceedings of 6th International Grassland Congress.1: 277-83.

Federer WT 1956. Experimental Designs theory and Applications McMillian, New York.

Fisher R A and Yates F 1963 Statistical Tables for Biological Agricultural and Medical Research. Oliver and Boyd, London pp: 46-63.

Hazra, P, Roy, A and Bandopadhyay, A. 2000. Growth characters as rhizome yield components of turmeric (Curcuma longa L.). Crop Research Hisar. 19(2): $235-40$.

Indiresh, K.M, Uthaiah, B.C., Reddy, M.J and Rao, K.B. 1992. Genetic variability and heritability studies in turmeric (Curcuma longa L.). Indian Cocoa, Arecanut and Spices Journal.26: 50-53.

Jan, H.U, Rabbani, M.A and Shinwari, Z.K. 2011.Assessment of genetic diversity of indigenous turmeric (Curcuma longa L.) germplasm from Pakistan using RAPD markers. Journal of Medicinal Plants Research. 5(5):82330.

Jan, H.U, Rabbani, M.A and Shinwari, Z.K. 2012.Estimation of genetic variability in turmeric (Curcuma longa L.) germplasm using agro-morphological traits. Pakistan Journal of Botany. 44(1): 23138.

Jayasree, M., Radhakrishnan, V.V and Mohanan, K.V. 2014. Assessment of variability and selection of promising genotypes in Mango Ginger (Curcuma amada Roxb.) accessions from Kerala.
Indian Journal of plant genetic Resources. 27(1): 54-58.

Johnson, H.W, Robinson, H.F and Comstock, R.E. 1955. Estimation of genetic environmental variability in soybean. Agronomy Journal. 47: 314-18.

Lynrah, P.G, Barua, P.K and Chakrabarty, B.K. 1998. Pattern of genetic variability in a collection of turmeric (curcuma spp) genotypes. Indian journal of genetics. 58(2): 201-07.

Manohar, A, Venkata, P, Reddy, Y.N and Ganesh, M. 2004.Variability and correlation studies in turmeric (Curcuma longa L.). Crop Research. 27: 275-81.

Pathania, N, Singh, $M$ and Arya, P.S. 1988.Genetic evaluation of some economic traits in turmeric (Curcuma longa L.). Himachal Journal Agricultural Research. 14 (1): 38-43.

Philip, P.J and Nair, P.C.S. 1985. Studies on variability, heritability and genetic advance in turmeric. Indian Cocoa Arecanut and Spices Journal. 8: 23-30.

Prajapati, K.N, Patel, M.A, Patel, J.R, Joshi, N.R, Patel, A.D and Patel, J.R. 2014. Genetic Variability, Character Association and Path Coefficient analysis in Turmeric (Curcuma longa L.). Electronic Journal of Plant Breeding. 5(1):131-37.

Rajyalakshmi, R, Naidu, L.N, Rajasekhar, M and Sudhavani, V. 2013. Journal of Spices and Aromatic Crops. 22(1): 10407.

Rao, A.M, Rao, P.V, Reddy, Y.N and Ganesh, M. 2004.Variability and correlation studies in turmeric (Curcuma longa L.). Journal of Crop Research (Hisar).27(2/3): 275-81.

Singh, A.P, Pandey, V.P, Rahman, S.M.A and Rashid, P. 2012. Genetic variability and character association in turmeric (Curcuma longa L.). Trends in Biosciences. 5(1): 11-13.

Singh, B. K and Ramakrishna, Y. 2014. 
Indian Collections of Turmeric Genetic Variability, Inheritance, Character Association and Performance studies in turmeric. Advances in Plant Sciences. 19(2): 639-42.

Singh, Y, Mittal, P and Katoch, V. 2003. Genetic variability and heritability in turmeric (Curcuma longa L.).Himachal Journal of Agricultural Research. 29(1/2): 31-34.

Sinker, P.V, Haldankar, P.M, Khandekar, R.G, Ranpise, S.A, Joshi, G.D. and Mahale, B.B. 2005.Preliminary evaluation of turmeric (Curcuma longa L.) varieties at Konkanregion of Maharashtra. Journal of Spices and Aromatic Crops. 14(1): 28-33.

Verma, S, Singh, S, Sharma, S, Tewari, S.K, Roy, R.K, Goel, A.K and Rana, T.S. 2015. Assessment of genetic diversity in indigenous turmeric (Curcuma longa) germplasm from India using molecular markers. Physiology and Molecular Biology of Plants. 21(2): 233-42.

\section{How to cite this article:}

Mamatha, K., M. B. N. Rao, BVK. Bhagavan, K. Umajyothi, M. Anuradha and Sivaraju, K. 2020. Studies on Genetic Variability and Heritability in Turmeric (Curuma longa L.). Int.J.Curr.Microbiol.App.Sci. 9(09): 329-335. doi: https://doi.org/10.20546/ijcmas.2020.909.042 